\title{
THE INFLUENCE OF VITAMIN D LEVELS ON ASTHMA CONTROL IN CHILDREN WHO ARE OVERWEIGHT OR OBESE
}

\author{
@V. I. Velychko, Y. O. Pychugina, O. I. Sandul \\ Odesa National Medical University of Family Medicine and General Practice
}

SUMMARY. Introduction. The amount of asthma incidence grows from year to year, starting in childhood, it accompanies a person throughout the whole life. Often asthma is aggravated by concomitant diseases that weaken the control of the underlying disease, because of this the life quality of patients significantly reduced.

Second in frequency of asthma related diseases occupy excessive body weight (overweight) and obesity. These pathologies have common pathogenesis, part of each is the deficiency of vitamin $D$.

The aim of the work - to examine the effect of vitamin D3 serum on asthma control in children with overweight or obese.

Materials and Methods. We examined the levels of Vitamin D in the blood serum of 60 children with asthma, some of whom were overweight or obese. The control group included 30 healthy children, without any somatic pathology on the background and harmonious physical development. Everyone underwent a single set of tests

Results. It was found that a deficiency of Vitamin D was associated with the level of asthma control and the presence of overweight or obesity burdened the state deficit and also the level of control of asthma.

Conclusion. Vitamin D deficiency affects the severity of asthma especially in children who are overweight or obesity.

KEY WORDS: asthma; asthma control; children; overweight; obesity; vitamin D.

Introduction. The amount of asthma incidence is growing from year to year, starting in childhood, it accompanies a person throughout the whole life such data is presented by the World Health Organization (WHO) in cooperation with Global Initiative for Asthma (GINA) [1]. Nowadays there are 300 million people suffering from this disease, 5-10\%children, half of them are teenagers [2].

In Ukraine, the prevalence of asthma is $4.4 \%$ and is estimated on the basis of applications, which is not enough to form a complete picture of morbidity. These official statistics of medical institutions is too low compared with the real situation. Thus, based on international medical programs ISAAC 2015 the prevalence of asthma among children in Ukraine 13-17 years old is $10.3 \%$ (according to the criteria ISAAC 11.6 cases per 100 subjects). Also, in Ukraine asthma is more found among urban residents $(11.3 \%)$, while among the rural population this mark is lower (9.3\%), and more often found among boys than girls. [3]

Often asthma is aggravated by concomitant diseases that weaken the control of the underlying disease, because of this the life quality of patients significantly reduced. Based on Asthma VIII Congress held in Kiev in 2014, second in frequency of asthma related diseases occupy excessive body weight (overweight) and obesity.

Amid asthma and overweight or obesity is a widespread problem in the world. Only in Ukraine $10-15 \%$ of children and adolescents suffer from overweight or obese. According to our data in Odesa region, in fact, this index is much higher than official statistics (15.34-31.52\%). The disparity in the prevalence and incidence of obese children population of Odesa region $(\mathrm{Q}=14.8 ; \mathrm{df}=2, \mathrm{p}<0.05)$ indicates the danger of further increase in the incidence of obesity and the need to develop a regional program for the prevention of alimentary-dependent diseases among children and adolescents.

According to the conducted in 2009 in the US meta-analysis, obesity is a major risk factor in the development of asthma, $38 \%$ of children with overweight and $92 \%$ of children who are suffering from obesity prone to development of asthma in comparing with children who have harmonious physical development [5]. Among children 5-17 years - $70 \%$ have at least one risk factor for the development of excess weight and obesity, $39 \%$ have 2 or more factors [7].

Scientific researches of recent years, held in Ukraine, Russia, Europe, USA, Japan, Iran and Egypt show that asthma and overweight or obesity accompany each other creating a vicious circle, which is extremely difficult to break without having a comprehensive approach. At the same time, vitamin $D$ deficiency is more common found in children. It is a global health issue covering more than 1 billion people [8].

Vitamin D effects on a few links in the chain of asthma pathogenesis as well as overweight or obese pathogenesis. First of all, this effect is caused be- 
Огляди літератури, оригінальні дослідження, погляд на проблему

cause of its ability to influence the cellular and humoral immunity, increasing the synthesis of inflammatory cytokines (IL-10) and reducing the synthesis of inflammatory cytokines (IL-4, IL-13) [10], thus reducing the inflammation process [6]. This mechanism is caused by gene expression and synthesis of cytokines. The point of application there are receptors for vitamin D. Calcitriol has a high affinity receptor for vitamin $D$. Vitamin $D$ receptors and vitamin $D$ metabolic enzymes have been found in many cells, $T$ and $B$ lymphocytes, macrophages, including alveolotsity lung and bronchial smooth muscle cells [9].

In recent years, there were researches confirming the clinical significance of this interrelation. In 2011, during one of such research was found the larger number of asthma exacerbations in patients with low levels of vitamin $D(25(\mathrm{OH}) \mathrm{D} \leq 30 \mathrm{ng} / \mathrm{ml})$. The number of exacerbations was reduced after 6 months of correction with vitamin D3 [11]. Italian doctors in 2012 examined 75 children aged 5 to 12 years with a diagnosis of asthma. It was noted that patients with low asthma control (based on the test control asthma by GINA) level of $25(\mathrm{OH}) \mathrm{D}$ was at the lower limit of normal [12]. Russian research confirmed that people with asthma and overweight or obese have more severe course in turn with increasing severity of asthma and decreasing of vitamin $D$ levels [4].

Metabolic status of vitamin D may play a key role in the pathogenesis of asthma, determining the severity of its course. The level of vitamin D statistically significantly depends on comorbidity status. Also in the literature of recent years widely discussed pleiotropic effects of vitamin $D$, including its effect on accumulation and metabolism of adipose tissue.

That's why it is possible to assume that the state of vitamin $D$ deficiency and overweight or obesity aggravate one another, and also influence the course of asthma by reducing disease control.

The aim of the work - to study the effect of vitamin D3 serum on asthma control in children with overweight or obese.

Materials and Methods. The study involved 60 patients (aged 6 to 11 years) with asthma mild to moderate severity. 30 patients who formed the main group (children with asthma in combination with overweight or obese), their body mass index (BMI) was $(19.97 \pm 0.36) \mathrm{kg} / \mathrm{m}^{2}, 30$ patients with asthma and harmonious physical development made a comparison group with BMI - $(16.17 \pm 0.25) \mathrm{kg} / \mathrm{m}^{2},(p<0.05)$. The control group included 30 healthy children, without any somatic pathology on the background and harmonious physical development. The severity of asthma and the degree of control the disease were evaluated according to the criteria of the Global Initiative for Asthma 2015 (GINA)
All the patients were conducted under the single set of diagnostic tests: general physical examination, anthropometric measurements and calculation of $\mathrm{BMI}$, determination of the hydroxigolicalferol levels in blood. Patients were not taken into research if they used vitamin $\mathrm{D}$ or calcium in the diet or signed information consent. The level of 25-(OH) D in serum was analyzed by ELISA. Blood sampling were conducted in winter. According to the recommendations of the US level of vitamin $D \geq 20 \mathrm{ng} / \mathrm{mL}$ is seen by us as ample use, $11-20 \mathrm{ng} / \mathrm{ml}$ - lack intake, $\leq 10 \mathrm{ng} / \mathrm{ml}$ - deficit. All analyzes were conducted from $8.00 \mathrm{am}$ to $10.00 \mathrm{am}$ on an empty stomach. The results that were obtained, processed in the program Statistics10, after checking the normal distribution method of variation statistics using Student t-test were considered statistically significant differences at $p<0.05$.

Results. The level of asthma control in children with asthma and overweight or obese was $(17.2 \pm 0.3)$ significantly lower than in children with asthma and harmonious physical development, their level of asthma control was $(18.6 \pm 0.4)(p<0.05) .15 \%$ of children comparison group had a sufficient level of control (the level of asthma control above 20 considered to be adequate).

Vitamin $D$ deficiency was observed in both groups, but in the main group it was significantly higher $(11.47 \pm 0.16) \mathrm{ng} / \mathrm{ml}$ than in the comparison group $(18.82 \pm 1.71) \mathrm{ng} / \mathrm{ml}$; $(p<0.05$, as compared with the control group of both groups, the difference is even more significant $-p<0.001 ; p<0.001$, respectively). In the control group the level of vita$\min \mathrm{D}$ was $(31.53 \pm 1.52) \mathrm{ng} / \mathrm{ml}$.

There were $27.5 \%$ of all patients with asthma who have a deficiency of vitamin D below $11 \mathrm{ng} / \mathrm{mL}$, they were all from the main group. The level of asthma control in these children was $(16.8 \pm 0.28)$. Lack of vitamin D had $52.5 \%$ rate of children and their asthma control was (18.6 \pm 0.4$)$; it was significantly higher than in children with deficiency of vitamin $D(p<0.05)$, but was still lower than $20.20 \%$ of all subjects with asthma have vitamin D levels above $20 \mathrm{ng} / \mathrm{ml}$, and have asthma control level (20.5 \pm 0.35$)$, this level is sufficient when asthma can be considered to be under control.

The correlation analysis of an interrelation of the studied parameters was held. Thus, it was found that in the study group relations between the level of control of asthma and vitamin $D$ levels directly $(r=0.77)$, power connection on a scale Cheddoka is high. In the comparison group the relations are strong and direct $(r=0.87)$.

So, this research clearly shows the dependence of asthma control levels and vitamin $D$ levels in children which can provide a prognostic criterion. Moreover, scarce condition can be corrected, such a cor- 
Огляди літератури, оригінальні дослідження, погляд на проблему

rection may positively affect the course of asthma in children, and raise the level of asthma control.

Conclusion. According to the analysis of the data was found a significant reduction of asthma control in children with asthma and overweight or obese compared to children with asthma and harmonious physical development. Vitamin D deficiency is presented in children with asthma, and it is more expressed in the association of the two pathologies.

\section{ЛІТЕРАТУРА}

1. Абатуров A. Е. Витамин D зависимая продукция антимикробных пептидов / А. Е. Абатуров // Здоровье ребенка. - 2012. - Т 1, № 36. - С. 103-106.

2. Аверьянов А. П. Ожирение у детей и подростков: клинико-метаболические особенности, лечение, прогноз и профилактика осложнений / А. П. Аверьянов // Международный эндокринологический журнал. 2009. - T. 4, № 22. - С. 28-32.

3. Ожирение и бронхиальная астма / Н. Г. Астафьева, Ю. В. Гамова, Е. Н. Вдовиченко, Ю. А. Перфилова // Лечащий врач. - 2014. - Т 4. - С. 8-12.

4. Купаев В.И. Особенности липидного обмена у больных бронхиальной астмой на фоне дефицита витамина D / В. И. Купаев, М. С. Горемикина, М. А. Косминина // Медицинские науки. Успехи современного естествознания. - 2015. - № 2. - С. 73-76.

5. Beuther D. A. Overweight, obesity, and incident asthma: a meta-analysis of prospective epidemiologic studies / D. A. Beuther, E. R. Sutherland // Am. J. Respir. Crit. Care Med. - 2007. - Vol. 175 (7). - P. 661-666.

6. Brüske I. Body mass index and the incidence of asthma in children / I. Brüske, C. Flexeder, J. Heinrich // Curr. Opin. Allergy Clin. Immunol. - 2014. - № 4. - P. 155-160.

\section{REFERENCES}

1. Abaturov, A. (2012). Vitamin D zavisimaya produktsiya antimikrobnykh peptidov [Vitamin D dependent production of antimicrobial peptides]. Zdorovye rebenkaChild's Health, 36 (1), 103-106 [in Russian].

2. Averyanov, A. (2009). Ozhyrenye u detey $i$ podrostkov: kliniko-metabolisticheskye osobennosti, lechenie, prognoz i profilaktika oslozhneniy. [Obesity in children and adolescents: clinically-metabolistic features, treatment, prognosis and prevention of obesity]. Mezhdunarodnyy endokrynologicheskyy zhurnal - International Endocrinology Journal, 4 (22), 28-32 [in Ukrainian].

3. Astafeva, N. \& Gamova, Y. (2014). Ozhyrenye i bronkhialnaya astma. [Obesity and bronchial asthma]. Lechashchyy vrach - Terapist, 12 (4), 8-12 [in Russian].

4. Kupaev, V. \& Horemykyna, M. (2015). Osobennosti lipidnogo obmena u bolnykh bronkhialnoy astmoy na fone deytsva vitamina $D$. [Features of lipid metabolism in patients with bronchial asthma and vitamin D deficiency]. Medytsynskye nauky. Uspekhy sovremennogo estestvoznaniya - Medical Sciences. Successes of Modern Natural Science, 7 (2), 73-76 [in Russia]
Also, it was found that the level of asthma control and the level of vitamin D tightly linked and burdened with concomitant pathology deficient condition is further worsen asthma control.

Further it is planned the correction of the deficit situation and monitoring the level of asthma control in these children.

Competing interests: The authors declare that they have no competing interests.

7. Dennison B. A. Television viewing and television in bedroom associated with overweight risk among lowincome preschool children / B. A. Dennison, T. A. Erb, P. L. Jenkins // Pediatrics. - 2002. - Vol. 109. - P. 1028-1035.

8. Glaucia Carneiro. Vitamin and mineral deficiency and glucose metabolisme A review / Glaucia Carneiro, Blandine Laferrère, Maria Teresa Zanella // e-SPEN Journal. - 2013. - Vol. 8. - P. 73-79

9. Guillot X. Vitamin D and inflammation / X. Guillot, L. Semerano, N. Saidenberg-Kermanac' // Joint Bone Spine - 2010. - Vol. 77. - P. 552-557.

10. Childhood obesity indeveloping countries: epidemiology, determinants, andprevention / N. Gupta, K. Goel, P. Shah, A. Misra // Endocrinological Review. 2012. - Vol. 33 (1). - P. 48-70.

11. Vitamin $D$ supplementation in children may prevent asthma exacerbation triggered by acute respiratory infection / P. Majak, M. Olszowiec-Chlebna, K. Smejda, J. Stelmach // Allergy Clin Immunol. - 2011. Vol. 127 (5). - P. 1294-1296.

12. Vitamin D serum levels and markers of asthma control in Italian children / G. Paul, J. M. Brehm, J. F. Alcorn [et al.] // Respir. Crit. Care Med. -2012. - Vol. 185 (2). - P. 124-132.

5. Beuther, D. \& Sutherland, E. (2007). Overweight, obesity, and incident asthma. American Journal of Respiratory and Critical Care Medicine, 175 (7), 661-666.

6. Brüske, I., Flexeder, C. \& Heinrich, J. (2014). Body mass index and the incidence of asthma in children. Current Opinion in Allergy and Clinical Immunology, 14 (2), 155-160.

7. Dennison, B., Erb, T. \& Jenkins, P. (2002). Television viewing and television in bedroom associated with overweight risk among low-income preschool children. Pediatrics, 109 (6), 1028-1035.

8. Carneiro, G., Laferrère, B. \& Zanella, M. (2013). Vitamin and mineral deficiency and glucose metabolism A review. e-SPEN Journal, 8 (3), e73-e79.

9. Mangin, M., Sinha, R. \& Fincher, K. (2014). Inflammation and vitamin $D$ : the infection connection. Inflammation Research, 63 (10), 803-819.

10. Gupta, N., Goel, K., Shah, P. \& Misra, A. (2012). Childhood obesity in developing countries: epidemiology, determinants, and prevention. Endocrine Reviews, 33 (1), 48-70. 
Огляди літератури, оригінальні дослідження, погляд на проблему

11. Majak, P., Olszowiec-Chlebna, M., Smejda, K. \& Stelmach, I. (2011). Vitamin D supplementation in children may prevent asthma exacerbation triggered by acute respiratory infection. Journal of Allergy and Clinical Immunology, 127 (5), 1294-1296.

12. Chinellato, I., Piazza, M., Sandri, M., Peroni, D., Piacentini, G. \& Boner, A. (2011). Vitamin D serum levels and markers of asthma control in italian children. The Journal of Pediatrics, 158 (3), 437-441.

\title{
ВПЛИВ РІВНЯ ВІТАМІНУ D НА КОНТРОЛЬ БРОНХІАЛЬНОЇ АСТМИ У ДІТЕЙ 3 НАДМІРНОЮ МАСОЮ ТІЛА АБО ОЖИРІННЯМ
}

\author{
๑В. І. Величко, Ю. О. Пичугіна, О. І. Сандул \\ Одеський національний медичний університет
}

PЕЗЮМЕ. Захворюваність на бронхіальну астму зростає з року в рік, дебютуючи у дитячому віці, вона супроводжує людину впродовж всього життя. Часто бронхіальна астма обтяжується супутньою патологією, що послаблює контроль над основним захворюванням, через що якість життя пацієнтів значно знижується. Друге місце за частотою серед захворювань, які супроводжують астму, займають надмірна маса тіла та ожиріння. Ці патології мають спільні ланки патогенезу, такі як дефіцит вітаміну D.

Мета-вивчити вплив рівня вітаміну $\mathrm{D}_{3}$ сироватки крові на контроль бронхіальної астми у дітей з надлишковою масою тіла або ожирінням.

Матеріал та методи. Проведено дослідження рівня вітаміну D в сироватці крові 60 дітей з бронхіальною астмою, частина з яких мала надмірну масу тіла або ожиріння. Групу контролю склали 30 здорових дітей з гармонійним фізичним розвитком. Усім був проведений єдиний комплекс обстежень.

Результати. Після обстеження було виявлено, що дефіцит вітаміну 25(OH)D асоційований з рівнем контролю астми, а наявність надмірної маси тіла або ожиріння ще більш обтяжує як дефіцитний стан, так і рівень контролю бронхіальної астми.

Висновки. Дефіцит вітаміну D помітно впливає на тяжкість бронхіальної астми, особливо у дітей з надмірною масою тіла або ожирінням

КлючовІ СлОВА: бронхіальна астма; астма-контроль; діти; надмірна маса тіла; ожиріння; вітамін D.

\section{ВЛИЯНИЕ УРОВНЯ ВИТАМИНА D НА КОНТРОЛЬ БРОНХИАЛЬНОЙ АСТМЫ У ДЕТЕЙ С ИЗБЫТОЧНОЙ МАССОЙ ТЕЛА ИЛИ ОЖИРЕНИЕМ}

\author{
๑В. И. Величко, Ю. А. Пичугина, О. И. Сандул
}

\author{
Одесский национальный медицинский университет
}

РЕЗЮМЕ. Заболеваемость бронхиальной астмой растет из года в год, дебютируя в детском возрасте, она сопровождает человека на протяжении всей жизни. Часто бронхиальная астма отягощается сопутствующей патологией, что ослабляет контроль над основным заболеванием, и качество жизни пациентов значительно снижается. Второе место по частоте среди сопутствующих астме заболеваний занимают избыточная масса тела и ожирение. Эти патологии имеют общие звенья патогенеза, такие как дефицит витамина D.

Цель - изучить влияние уровня витамина $\mathrm{D}_{3}$ сыворотки крови на контроль бронхиальной астмы у детей с избыточной массой тела или ожирением.

Материал и методы. Проведено исследование уровня витамина D в сыворотке крови 60 детей с бронхиальной астмой, часть из которых имела избыточную массу тела или ожирение. Группа контроля составила 30 здоровых детей с гармоничным физическим развитием. Всем был проведен единый комплекс обследований.

Результаты. После обследования было выявлено, что дефицит витамина $D_{3}$ ассоциирован с уровнем контроля астмы, а наличие избыточной массы тела или ожирения еще более отягощает как дефицитное состояние, так и уровень контроля бронхиальной астмы.

Выводы. Дефицит витамина D заметно влияет на тяжесть бронхиальной астмы, особенно у детей с избыточной массой тела или ожирением.

КЛЮчЕВЫЕ СЛОВА: бронхиальная астма; астма-контроль; дети; избыточная масса тела; ожирение; витамин D. 